\title{
Influence of Irrigation Regimes and Nitrogen Levels on Growth, Yield and Economics of Summer Sesame
}

\author{
Kalpana Jamdhade, Anita Chorey*, Bharti Tijare and V.M. Bhale \\ Department of Agronomy, Dr. Panjabrao Deshmukh Krishi Vidyapeeth, \\ Akola-444104, (M.S), India \\ *Corresponding author
}

\begin{tabular}{|c|c|}
\hline & B S T R A \\
\hline & \multirow{6}{*}{ 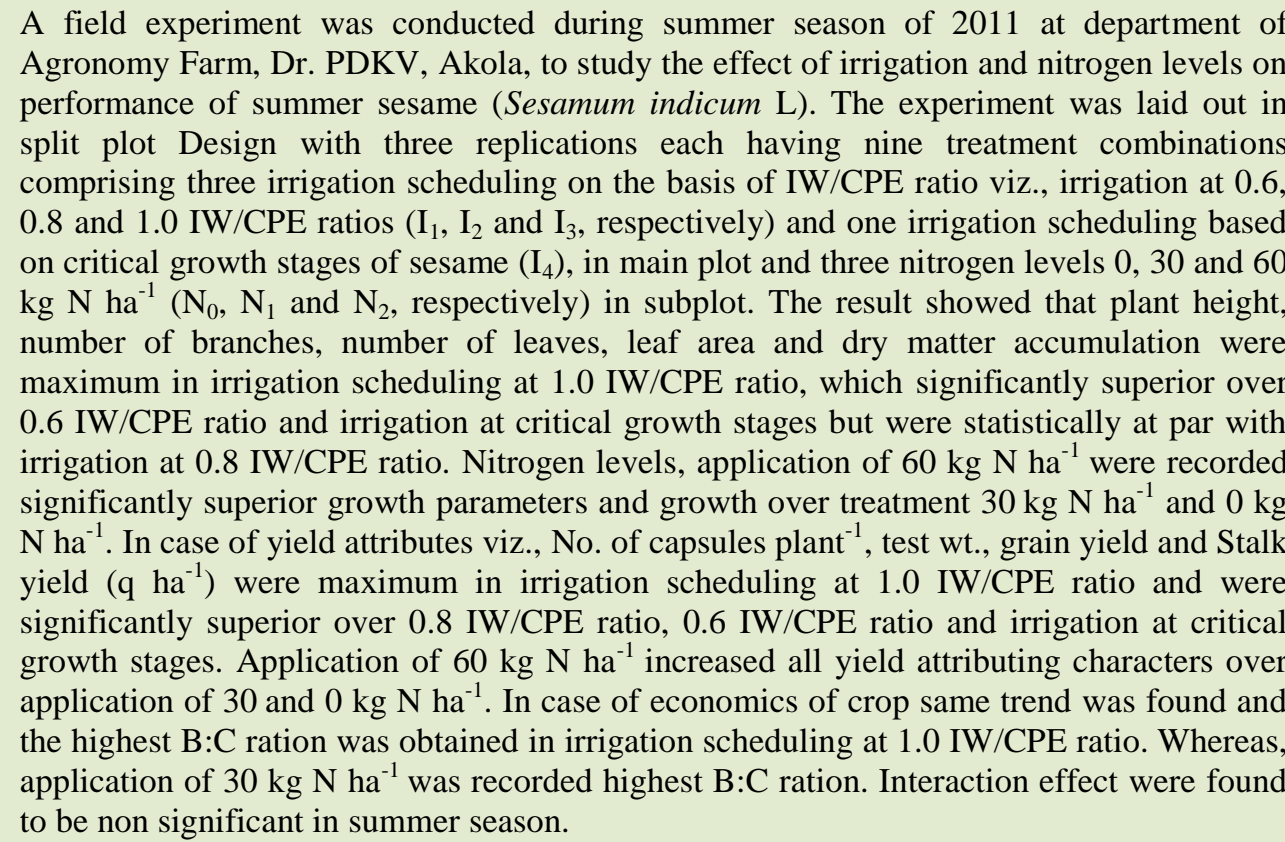 } \\
\hline Keywords & \\
\hline $\begin{array}{l}\text { Irrigation regimes, } \\
\text { Nitrogen levels } \\
\text { and summer } \\
\text { sesame. }\end{array}$ & \\
\hline Article Info & \\
\hline $\begin{array}{l}\text { Accepted: } \\
\text { 24 February } 2017 \\
\text { Available Online: } \\
12 \text { March } 2017\end{array}$ & \\
\hline & \\
\hline
\end{tabular}

\section{Introduction}

Sesame (Sesamum indicum L.) is most ancient and multipurpose oilseed crop which is cultivated almost throughout India for its high quality oil and tremendous potential to export sesame in the world. India is the largest oilseed growing country with $20 \%$ of world's area, but third in oilseed production due to inferior productivity. In India sesame is cultivated on 1.86 million ha area with annual production of 0.81 million ton. Its average productivity $\left(437 \mathrm{~kg} \mathrm{ha}^{-1}\right)$ is much below than that of the world $\left(489 \mathrm{~kg} \mathrm{ha}^{-1}\right)$ (FAO, 2009). Lower production of sesame is due to the predominant cultivation under conditions of low and uncertain rainfall and input starvation with poor management. Water is immortal input, irrigation scheduling on the basis of IW/CPE ratio has an important 
influence on growth and productivity of the crop because it provides accurate water requirement to meet the demands of evaporation, transpiration and metabolic needs of the crop. Assured supply of water through efficient irrigation practice is an essential basic input for obtaining higher yield. To achieve higher productivity potential, irrigation scheduling and balanced fertilization are the key factors. Narang and Gill (1998) reported that seed yield of summer sesame increased with increase in number of irrigations. Keeping in view, fast ever diminishing water resources and increasing competition from and within agriculture for water, its economical and efficient utilization becomes quiet imperative. Under limited water supply, higher yield can be obtained by proper irrigation scheduling (Choradia and Gaur, 1986).

Nitrogen is the most limiting nutrient for crop production in many regions of the world and nitrogen fertilizer is an effective but expensive input used by farmers to achieve desired crop yields. Nitrogen plays an important role in almost all plant metabolic processes and also needed for the synthesis of chlorophyll which is required for photosynthesis. New leaves may contain up to $6 \% \mathrm{~N}$. It is a very mobile nutrient and moves from older to newer leaves as the plant ages. Nitrogen is taken up throughout the growing season and it is transported and stored in the leaves. The $\mathrm{N}$ requirements for capsule development are partially met from $\mathrm{N}$ stored in the leaf canopy. The deficiency of nitrogen results in poor growth and yield. Nitrogen is one of the factors that directly influence vegetative growth and dry matter production (Malik et al., 2003). It is well established fact that there is positive correlation between nitrogen application and productivity. Hence, summer cultivation was practiced with irrigation scheduling and nitrogen application in split, which plays important role in summer sesame production. The present experiment was carried out to study the effect of different irrigation regimes and nitrogen levels on growth and productivity of summer sesame.

\section{Materials and Methods}

A field experiment was conducted during summer season of 2011 at department of Agronomy Farm, Dr. PDKV, Akola, to study the effect of irrigation scheduling and nitrogen levels on performance of summer sesame (Sesamum indicum L.). The soil of experimental field was clay loam in texture and slightly alkaline in reaction $(\mathrm{pH} 7.79)$, however, good for EC (0.374).It was analyzed low in available nitrogen (221.41 kg ha $\left.{ }^{-1}\right)$, medium in organic carbon $\left(0.43 \mathrm{~g} \mathrm{~kg}^{-1}\right)$, medium in available phosphorus $(16.86 \mathrm{~kg}$ ha $\left.{ }^{-1}\right)$ and high in available potassium $(365.25 \mathrm{~kg}$ ha $\left.{ }^{-1}\right)$. The treatments comprised of three irrigation scheduling on the basis of IW/CPE ratio viz., irrigation at $0.6,0.8$ and 1.0 IW/CPE ratios $\left(I_{1}, I_{2}\right.$ and $I_{3}$, respectively) and one irrigation scheduling based on critical growth stages of sesame $\left(\mathrm{I}_{4}\right)$, in main plot and three nitrogen levels 0,30 and $60 \mathrm{~kg} \mathrm{~N}^{-1}$ $\left(\mathrm{N}_{0}, \mathrm{~N}_{1}\right.$ and $\mathrm{N}_{2}$, respectively) in subplot. All these treatments were tested in split plot design with three replications. The Sesame variety AKT -1 was sown on 23 February and harvested on 30 may 2011.

During the crop period, mean maximum temperature varied from $33.5^{\circ} \mathrm{C}$ to $43.4^{0} \mathrm{C}$ and mean minimum temperature varied from $15.3^{0} \mathrm{C}$ to $28.7^{0} \mathrm{C}$. The total evaporation during crop growth period was recorded $219.08 \mathrm{~mm}$.

\section{Results and Discussion}

\section{Growth parameters}

Maximum plant height, number of branches, number of leaves, leaf area and dry matter accumulation were recorded by irrigation scheduling at $1.0 \mathrm{IW} / \mathrm{CPE}$ ratio and was 
significantly superior over $0.6 \mathrm{IW} / \mathrm{CPE}$ ratio and irrigation at critical growth stages but statistically at par with irrigation at 0.8 IW/CPE. It might be due to adequate moisture supply throughout the crop growth period due to irrigations at a narrower interval, which might have resulted in better cell division and cell elongation, higher interception of solar radiation and more carbon partitioning, soil moisture and light are not limiting and higher temperature accelerates growth processes. Similar findings were also reported by Dutta et al., (2000), Sarkar et al., (2010) and Zeinolabedin and Moosavi (2011).

Application of nitrogen had significant influence on plant height, number of branches, number of leaves, leaf area and dry matter accumulation at all the stages of crop growth. There were significant increases with increase in level of nitrogen up to $60 \mathrm{~kg} \mathrm{~N}$ ha 1. Maximum of these parameters were recorded with application of $60 \mathrm{~kg} \mathrm{~N}^{-1}$ which were superior over treatment $30 \mathrm{~kg} \mathrm{~N}$ $\mathrm{ha}^{-1}$ and the lowest values were recorded with treatment $0 \mathrm{~kg} \mathrm{~N}^{-1}$. Nutrient nitrogen might have increased vegetative growth and meristematic activity of sesame which resulted into better gain in the weight of the plant involved in boosting of number of branches through participating in cell enlargement and encourages formation of new cells, thereby increasing the nutrient absorption and development of auxiliary buds in plants. Similar results were also reported by Subrahamaniyan and Arulmozhi (1999), Malik et al., (2003), Sarkar et al., (2010) and Zeinolbedin and Moosavi (2011).

Table.1 Effect of irrigation and nitrogen levels on growth parameters of summer Sesame

\begin{tabular}{|c|c|c|c|c|c|}
\hline Treatments & $\begin{array}{l}\text { Plant } \\
\text { height } \\
(\mathrm{cm})\end{array}$ & $\begin{array}{l}\text { No. of } \\
\text { Branches } \\
\text { plant }^{-1}\end{array}$ & $\begin{array}{l}\text { No. of } \\
\text { leaves } \\
\text { plant }^{-1}\end{array}$ & $\begin{array}{l}\text { Leaf area } \\
\left(\mathbf{d m}^{2}\right)\end{array}$ & $\begin{array}{l}\text { Total dry matter } \\
\text { accumulation }(\mathrm{g})\end{array}$ \\
\hline \multicolumn{6}{|c|}{ Irrigation scheduling } \\
\hline $\mathrm{I}_{1}-0.6 \mathrm{IW} / \mathrm{CPE}$ & 77.60 & 4.20 & 77.49 & 7.24 & 15.86 \\
\hline $\mathrm{I}_{2}-0.8 \mathrm{IW} / \mathrm{CPE}$ & 82.58 & 4.28 & 81.47 & 8.17 & 19.20 \\
\hline $\mathrm{I}_{3}-1.0 \mathrm{IW} / \mathrm{CPE}$ & 84.27 & 4.48 & 84.27 & 8.22 & 21.19 \\
\hline $\mathrm{I}_{4}-\mathrm{ICGS}$ & 77.42 & 3.58 & 77.42 & 7.02 & 14.48 \\
\hline $\mathrm{SE}(\mathrm{m}) \pm$ & 1.38 & 0.073 & 1.35 & 0.17 & 0.64 \\
\hline $\mathrm{CD}(\mathrm{P}=0.05)$ & 4.80 & 0.25 & 4.67 & 0.60 & 2.22 \\
\hline \multicolumn{6}{|l|}{ Nitrogen levels } \\
\hline $\mathrm{N}_{0^{-}} 0 \mathrm{KgNha}^{-1}$ & 76.26 & 3.98 & 76.18 & 7.03 & 16.16 \\
\hline $\mathrm{N}_{1}-30 \mathrm{KgNha}^{-1}$ & 80.45 & 4.14 & 80.45 & 7.82 & 17.62 \\
\hline $\mathrm{N}_{2}-60 \mathrm{KgNha}^{-1}$ & 84.68 & 4.30 & 84.68 & 8.14 & 19.25 \\
\hline $\mathrm{SE}(\mathrm{m}) \pm$ & 1.20 & 0.070 & 1.16 & 0.15 & 0.26 \\
\hline $\mathrm{CD}(\mathrm{P}=0.05)$ & 3.61 & 0.21 & 3.49 & 0.44 & 0.78 \\
\hline \multicolumn{6}{|c|}{ Interaction effect } \\
\hline $\mathrm{SE}(\mathrm{m}) \pm$ & 1.63 & 0.04 & 1.93 & 0.45 & 0.77 \\
\hline $\mathrm{CD}(\mathrm{P}=0.05)$ & NS & NS & NS & NS & $\mathrm{NS}$ \\
\hline
\end{tabular}


Table.2 Effect of irrigation and nitrogen levels on yield and economics on summer sesame

\begin{tabular}{|c|c|c|c|c|c|c|c|}
\hline Treatments & $\begin{array}{l}\text { No. of } \\
\text { capsul } \\
\text { es pl-1 }\end{array}$ & $\begin{array}{l}\text { Test } \\
\text { Wt. (g) }\end{array}$ & $\begin{array}{l}\text { Grain } \\
\text { yield } \\
\left.(\mathbf{q ~ h a})^{-1}\right)\end{array}$ & $\begin{array}{l}\text { Stalk } \\
\text { yield } \\
\left(\text { qha }^{-1}\right)\end{array}$ & $\begin{array}{l}\text { GMR } \\
\left.\text { (Rs.ha }^{-1}\right)\end{array}$ & $\begin{array}{l}\text { NMR } \\
\left.\text { (Rs.ha }^{-1}\right)\end{array}$ & $\begin{array}{l}\mathrm{B}: \mathrm{C} \\
\text { ratio }\end{array}$ \\
\hline \multicolumn{8}{|c|}{ Irrigation scheduling } \\
\hline $\mathrm{I}_{1}-0.6 \mathrm{IW} / \mathrm{CPE}$ & 33.72 & 2.50 & 4.33 & 42.64 & 31942 & 14232 & 1.84 \\
\hline $\mathrm{I}_{2}-0.8 \mathrm{IW} / \mathrm{CPE}$ & 42.75 & 3.20 & 4.46 & 44.84 & 33097 & 14714 & 1.84 \\
\hline $\mathrm{I}_{3}-1.0 \mathrm{IW} / \mathrm{CPE}$ & 47.85 & 3.30 & 5.22 & 54.61 & 39118 & 18527 & 1.95 \\
\hline $\mathrm{I}_{4}-\mathrm{ICGS}$ & 29.17 & 2.30 & 4.07 & 40.10 & 30050 & 11100 & 1.61 \\
\hline $\mathrm{SE}(\mathrm{m}) \pm$ & 1.31 & 0.05 & 0.15 & 1.73 & 994.36 & 1214.4 & - \\
\hline $\mathrm{CD}(\mathrm{P}=0.05)$ & 4.53 & 0.19 & 0.53 & 5.99 & 3444.62 & 4202.6 & - \\
\hline \multicolumn{8}{|l|}{ Nitrogen levels } \\
\hline $\mathrm{N}_{0^{-}} \mathbf{0 K g N h a}^{-1}$ & 35.88 & 2.55 & 4.27 & 39.92 & 30489 & 12588 & 1.71 \\
\hline $\mathrm{N}_{1}-30 \mathrm{KgNha}^{-1}$ & 37.99 & 2.76 & 4.50 & 45.63 & 32524 & 15213 & 1.88 \\
\hline $\mathrm{N}_{2}-60 \mathrm{KgNha}^{-1}$ & 41.25 & 3.17 & 4.79 & 51.10 & 34838 & 16130 & 1.86 \\
\hline $\mathrm{SE}(\mathrm{m}) \pm$ & 0.67 & 0.07 & 0.084 & 0.68 & 563.7 & 600 & - \\
\hline $\mathrm{CD}(\mathrm{P}=\mathbf{0 . 0 5})$ & 2.02 & 0.21 & 0.25 & 2.04 & 1690.1 & 1799.1 & - \\
\hline \multicolumn{8}{|c|}{ Interaction effect } \\
\hline $\mathrm{SE}(\mathrm{m}) \pm$ & 1.59 & 0.21 & 0.06 & 0.87 & 379.98 & 609.08 & - \\
\hline $\mathrm{CD}(\mathrm{P}=0.05)$ & NS & NS & NS & NS & NS & NS & - \\
\hline
\end{tabular}

\section{Yield and economics}

Effects of irrigation levels on yield attribute were found to be significant. Irrigation at 1.0 IW/CPE ratio recorded the highest No. of capsules plant ${ }^{-1}$, Test wt., Grain yield and Stalk yield $\left(\mathrm{qha}^{-1}\right)$ which were significantly superior over $0.8 \mathrm{IW} / \mathrm{CPE}, 0.6 \mathrm{IW} / \mathrm{CPE}$ and irrigation at critical growth stages. Higher irrigation frequencies provided proper availability of water at reproductive phase when plant needs more moisture, favorable temperature during their growth period resulting better translocation of photosynthates and accumulation of food to the site of capsule formation. These findings are in agreement with those reported by Ashok Kumar et al., (1996), Duraisamy et al., (1999), Dutta et al., (2000) and Sarkar et al., (2010).

Irrigation treatments significantly influenced the GMR, NMR and B:C ratio. The highest gross monetary return, net monetary return and $\mathrm{B}: \mathrm{C}$ ratio was obtained with application of irrigation scheduling at $1.0 \mathrm{IW} / \mathrm{CPE}$ followed by $0.8 \mathrm{IW} / \mathrm{CPE}$ and $0.6 \mathrm{IW} / \mathrm{CPE}$ and lowest was found under irrigation at critical growth stages treatment.

Effect of Nitrogen application on yield attributes and economics were found to be significant. Application of nitrogen at $60 \mathrm{~kg} \mathrm{~N}$ ha $^{-1}$ recorded maximum no. of capsules plant ${ }^{1}$, test wt., grain yield and stalk yield $\left(\mathrm{qha}^{-1}\right)$ over 30 and $0 \mathrm{~kg} \mathrm{~N} \mathrm{ha}^{-1}$. This is might be due to more accumulation of nitrogenous substances and better translocation of photosynthates to reproductive organs thereby efficient grain filling by application of nitrogen doses. Similar results were also reported by Ashok Kumar et al., (1996), Subrahamaniyan and Arulmozhi (1999), Malik et al., (2003), Abdal salam and AlShebani (2010) and Sarkar et al., (2010). 
Treatment $60 \mathrm{~kg} \mathrm{~N} \mathrm{ha}^{-1}$ recorded highest GMR and NMR followed by $30 \mathrm{~kg} \mathrm{~N} \mathrm{ha}^{-1}$ and $0 \mathrm{~kg} \mathrm{~N} \mathrm{ha}{ }^{-1}$. But in case of $\mathrm{B}$ : $\mathrm{C}$ ration application of $30 \mathrm{~kg} \mathrm{Nha}^{-1}$ recorded highest $\mathrm{B}$ : $\mathrm{C}$ ratio (1.88) followed by $60 \mathrm{~kg} \mathrm{Nha}^{-1}$ (1.86) and $0 \mathrm{~kg} \mathrm{Nha}^{-1}(1.71)$.

\section{Interaction Effect}

The interaction effect between irrigation scheduling and nitrogen levels were found to be non significant in summer cultivation of sesame.

\section{References}

Abdal Salam, A.A. and Al-Shebani, Y.A. 2010. Phonological and productivity characteristics of sesame (Sesamum indicum $\mathrm{L}$.) as affected by nitrogen rates under SANA'A conditions. J. Plant Production, 1(2): 251-264.

Anonymous. 2009. Food and Agriculture Commodities Production, FAOSTAT.

Ashok Kumar, Prasad, T.N. and Prasad, U.K. 1996. Effect of irrigation and nitrogen on growth, yield, oil content, nitrogen uptake and water-use of summer sesame (Sesamum indicum L.). Indian $J$. Agron., 41(1): 111-115.

Choradia, R.K. and Gaur, B.L. 1986. Effect of irrigation and mulch on seed yield of sunflower. Indian J. Agron., 31(3): 298299.

Dutta, D., Jana, P.K., Bandyopadhyay, P. and Maity, D. 2000. Response of summer sesame (Sesamum indicum L.) to irrigation. Indian J. Agron., 45(3): 613616.

Duraisamy, K., Kathiresan, G. and Balasubramanian, A. 1999. Effect of irrigation frequency and coir pith application in sesame (Sesamum indicum L.) Indian J. Agron., 44(2): 416-418.

Malik, M.A., Saleem, M.F., Cheema M.A. and Ahmed, S. 2003. Influence of different nitrogen levels on Productivity of sesame (Sesamum indicum L.) under varying planting patterns. Int. J. Agril. Biol., 5(4): 490-492.

Narang, R.S. and Gill, M.S. 1998. Irrigation scheduling for higher WUE in oilseed and pulses. Fertilizer News, 43(3): 5767.

Sarkar, A., Sarkar, S., Zaman, A. and Rana, S. K. 2010. Performance of summer sesame (Sesamum indicum L.) under different irrigation regimes and nitrogen levels. Indian J. Agron., 55(2): 143-146.

Subrahmaniyan, K. and Arulmozhi, N. 1999. Response of sesame (Sesamum indicum L.) to plant population and nitrogen under irrigated condition. Indian $J$. Agron., 44(2): 413-415.

Zeinolabedin and Moosavi, S.G. 2011. Study of effect different levels of irrigation Interval, nitrogen and super absorbent on seed yield and morphological Traits of sesame. Australian J. Basic and Appl. Sci., 5(10): 1917-1923.

\section{How to cite this article:}

Kalpana Jamdhade, Anita Chorey, Bharti Tijare and V.M. Bhale. 2017. Influence of Irrigation Regimes and Nitrogen Levels on Growth, Yield and Economics of Summer Sesame. Int.J.Curr.Microbiol.App.Sci. 6(3): 2389-2393. doi: https://doi.org/10.20546/ijcmas.2017.603.273 